\title{
Me While I am Learning Mathematics: Reflections to Elementary School Students' Drawings
}

\author{
Sedat Turgut ${ }^{*}$, ilknur Gülşen Turgut ${ }^{b}$
}

\author{
Received \\ Revised \\ Accepted \\ DOI \\ Corresponding Author: Sedat Turgut \\ Department of Primary Education, Faculty of \\ Education, Bartin University, Bartin, Turkey \\ E-mail: sdtturgut42@hotmail.com \\ ORCID: http://orcid.org/0000-0002-6612-9320
}

bilknur Gülşen Turgut.

Department of Mathematics and Science Education, Faculty of Education, Kutahya Dumlupinar University, Kutahya, Turkey.

E-mail: ilknurgulsen@gmail.com

ORCID: http://orcid.org/0000-0002-1721-7498

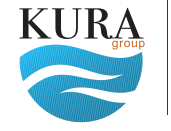

Copyright (C)

www.iejee.com

ISSN: 1307-9298

(c) 2020 Published by KURA Education \& Publishing. This is an open access article under the CO BY- NC- ND license. (https://creativecommons. org/licenses/by/4.0/)

\begin{abstract}
Each child will not become senior mathematicians in the future but all children have the right to get learning opportunities which he/she can develop his/her mathematical understanding at school. The success of children in mathematics is closely related to how they are taught mathematics. At this point, the role of teaching mathematics stands out in elementary school since they first encounter mathematics as a subject. Elementary school is the place where students first experience success or failure in mathematics. Therefore, the fundamentals of students' tendencies towards mathematics which will set and affect their future learning life are also laid here. The present study aims to examine the perceptions of elementary school students towards learning mathematics by means of their drawings. Drawings are tools for children to express themselves; they provide information about students' drawings on their classes and their understanding of teaching. In this context, based on the experiences of elementary school students, the phenomenon of learning mathematics was aimed to be defined from their perspective. This research employed phenomenology as a qualitative research design. The study group of the research consisted of 326 elementary school students. The data were collected through the drawings of students on the subject of "me while I am learning mathematics". Content analysis was used in the analysis of the data. According to the research results, it is seen that the math learning environment is usually classroom; people in the learning environment are usually teacher and student(s); materials in the learning environment are general items in the classroom environment; symbols in the learning environment are usually numeral-number-four operation symbols; learning mathematics is usually happy-enjoyable-fun and the process of learning mathematics is usually to do arithmetic.
\end{abstract}

\section{Keywords:}

Drawing, Elementary Students, Learning Math

\section{Introduction}

Times oday's children are growing up in a kind of world where mathematics is effective in all areas of life. The basics of the rapidly developing technology depend on mathematical knowledge. Many education and career opportunities require mathematical expertise. Individuals 
need mathematical calculations and analysis for their daily work in the natural flow of life (Haylock \& Thangata, 2007; Kilpatrick, Swafford, \& Findell, 2001). Therefore, it can be stated that every individual should have basic mathematical skills.

Mathematics is a creative discipline and part of modern life. It equips children with powerful tools that include skills such as logical reasoning, abstract thinking and problem solving to comprehend and change the world (Department for Education and Employment [DfEE], 1999). It gives children the responsibilities necessary not only for their future positions, but also for being active citizens (Goulding, 1997). It can be expressed that the goals of mathematics teaching are in general an individual to be able to cope with the mathematical demands of daily life, gain the basic numerical knowledge and skills that he or she will need, and develop types of mathematical thinking skills that will develop his or her intellectual capacity (Haylock \& Thangata, 2007).

\section{Theorical Framework}

Individuals begin learning mathematics before they reach elementary school. Starting from infancy, they encounter some situations related to numbers at any age and develop some mathematical skills (Kilpatrick et al., 2001). However, these skills are limited. Children need to understand mathematics so that they can enjoy learning it (Haylock, 2010). They are willing to do and understand it when they first encounter mathematics (Kilpatrick et al., 2001). Therefore, they need to build mathematics by means of reasoning, problem solving, discovery, discussion and practical experiences (Haylock, 2010). Otherwise, mathematics will refer to some procedures learned to achieve specific goals, which causes them to move away from mathematics over time. Because of the reasons previously stated, children who learn mathematics as procedures cannot employ and apply it except in situations similar to those taught (Davis, Goulding, \& Suggate, 2017).

Not all children will become senior mathematicians in the future. Some of them will use it more as part of their job in the future, while others will use it at a basic level to continue their daily life. However, every child has the right to receive learning opportunities which provide them with developing their mathematical conception according to their individual potential at school (Edwards, 2007). All children should be provided with opportunities and be supported so that they can understand and learn mathematics (National Council of Teachers of Mathematics [NCTM], 2000). It can be said that their success in mathematics is closely related to how they are taught mathematics. In this context, the role of teaching mathematics appears in the elementary school, where they first encounter mathematics as a subject. Elementary school is the place where they first experience success or failure in mathematics. Consequently, the fundamentals of students' tendencies towards mathematics are laid in elementary education. The effects of teachers on students' mathematics achievement are higher in elementary school than in later years (Hill et al., 2008). Elementary school teachers introduce students to mathematical language, symbolism, and ways of thinking. This introduction includes teaching the basic skills that students will need in their future education years (Cowan, 2006; Lerman, 1998). Elementary school teachers should use interesting, motivating and encouraging mathematical tasks and activities in the classroom so that the situation above can happen effectively (Cowan, 2006). Moreover, enabling learning process to interact with the real world by moving out of the classroom provides students with the opportunity to realize the applicability of mathematics in different environments and concrete experiences. Thus, students can regard mathematics as enjoyable and useful through mathematical experiences in elementary school, and they can develop positive attitudes by valuing mathematics. In addition, elementary school teachers need to create learning environments that support student participation in the mathematics teaching process (National Research Council [NRC], 2000). It can be stated that learning environments where students can express their own ideas and discuss their ideas with each other and their teachers provide students with opportunities to develop strong mathematical ideas, deep insights, discoveries, and new knowledge. Such learning environments serve to develop mathematical motivation and increase self-confidence of students.

Many children experience negative emotions such as anxiety, tension or discomfort when faced with mathematics (Carey et al., 2019). After compulsory education, many students think of making use of mathematics to an extent while not encountering mathematics (Borthwick, 2011). This situation can negatively affect the education and entire life of children (Duncan et al., 2007). Therefore, it will be effective in resolving the problem to determine the perceptions of students about teaching mathematics during elementary school and to consider them while making decisions about teaching. Determining the perceptions of children about the problem in resolving these problems related to teaching process will be beneficial to address them.

Students' drawings about their classrooms provide rich data on their perceptions about teaching (Weber \& Mitchell, 1999). Drawings are a tool for children to express themselves. By means of drawings, they can reflect their inner world, express their feelings, and give 
clues about personality traits. They can transfer their perceptions about the world and their relationships with people, objects, and places that they consider important. Drawings are unique individual expressions that can represent many different aspects of children (Anning \& Ring, 2004; Malchiodi, 1998). They can also express situations that they cannot express orally or in writing with their drawings. Moreover, the drawings encourage children to participate actively in research, as they are creative and fun. Unlike interviews that require children to respond more quickly, drawings give children time to think about what they want to animate in their drawings (Punch, 2002).

\section{The Present Study}

In the literature, there are studies examining by means of drawings secondary school students' perceptions of mathematician (Hatısaru \& Çetinkaya, 2012; Picker \& Berry, 2000; Toluk Uçar, Pişkin, Akkaş, \& Taşçı, 2010), mathematics (Yavuz Mumcu, 2020), and mathematics teacher (Gökçek \& Güneş, 2011); high school students' perceptions of mathematician (Aguilar, Rosas, Zavaleta, \& Romo-Vázquez, 2016; Grevholm, 2010); elementary school students' perceptions of mathematician (Rock \& Shaw, 2000) and mathematics lesson (Borthwick, 2011) and the way prospective teachers' were taught and the way they want to teach mathematics in the future (Lee \& Zeppelin, 2014). These studies which generally examine the perception of mathematician, employed middle school students in their sample. The present study aims to examine the perceptions of elementary school students towards learning mathematics by means of their drawings. In this context, based on the experiences of elementary school students, the phenomenon of "learning mathematics" is intended to define from their perspective. It is thought that defining how "learning mathematics" is perceived by elementary school students as a result of common experiences will provide valuable tips for mathematics teachers and especially elementary school teachers.

\section{Method}

\section{Research Design}

Phenomenological approach was employed in this study. In phenomenology, the essence, meaning or structure of these experiences are intended to be understood by focusing on the subjective experiences of individuals related to a case (Creswell, 2007; Merriam \& Grenier, 2019; Patton, 2015). For this purpose, it is attempted to define how the phenomenon is perceived from participants' perspective, by collecting data from individuals who experience the researched case. This process focuses on the common points in the experiences of individuals (Creswell, 2007). Based on this, the phenomenon of "learning mathematics" was investigated by means of the drawings of elementary school students. It may be desirable to examine children's drawings from a phenomenological perspective since it gives us the opportunity to view the drawings from various perspectives. However, attributing a meaning to only the drawings can cause misinterpretations. It is appropriate to evaluate various factors that affect how, what, and why children draw together (Malchiodi, 1998). For this purpose, it was considered to conduct interviews with children about their drawings. However, no interview was conducted due to the reasons such as some of the children at the elementary school level not wanting to talk, as suggested by their teachers, and that they could not express what they wanted to say, and because of the high number of participants. Instead, the students were asked to explain their drawings in a few sentences.

\section{Study Group}

Convenience sampling method was employed in order to determine the study group of the research. In this method, it is considered that the access to the participants is easy, that the participants are suitable for research and available for participation in the study (Neuman, 2014). In this context, the study group of the research consists of 326 elementary school students who continue their education in Bartın Province in the second semester of the 2018-2019 academic year. Among of the study group, 25 students ( 13 girls, 12 boys) were in 1st grade, 109 students (52 girls, 57 boys) were in 2nd grade, 86 students (36 girls, 50 boys) were in 3 rd grade, and 106 students (55 girls, 51 boys) were in 4th grade.

\section{Data Collection Process}

There are various data formats collected in a phenomenological research (Creswell, 2016). In this study, the data were collected with the students' drawings and written explanations expressing these drawings. For this purpose, firstly, schools planned to collect data were visited. School administrators and elementary school teachers were informed about the research. Secondly, the elementary school teachers, whose the classroom was suitable for the research, were asked to read the instruction written by the researcher and distribute the papers prepared for drawing in the classrooms they teach in the visual arts class. It can be stated that they can make more detailed explanations if needed. The instructions are as follow: I would like you to make a drawing on "Me while I am learning mathematics". Your drawing should reflect how you think about learning mathematics. For this purpose, think about what your drawing will contain for a few minutes before you 


\section{iejee}

start drawing. When someone looks at your drawing, he or she should be able to see how you perceive learning mathematics. I will give you a piece of paper to draw. You can make your drawing on the paper bordered by a frame. Explain your drawing with a few sentences on the lines placed under the frame. While drawing, you can use a coloured pencil if you want. Please do not look at each other's drawings while you are drawing, just draw your own thought. In this way, the application process was carried out in six different classes, in ten different elementary schools at different times and in accordance with the curriculum.

\section{Data Analysis}

In the design of phenomenology, the researcher interprets the meanings of common experiences based on the data obtained, reduces the information obtained in the research to important expressions or quotations and combines them into categories and analyses the data (Creswell, 2007). Based on this, content analysis was employed in data analysis. Content analysis involves coding, categorizing, linking categories, and making theoretical conclusions (Cohen, Manion, \& Morrison, 2018) and it is a useful method of analysing perceptions (Julien, 2008). In the analysis of the data, each grade level was analysed separately. In the analysis process, in order to interpret the drawings correctly, explanations about the drawings and drawings of the students were evaluated together. Each drawing was examined several times by two researchers, and in each examination, descriptions related to the drawings were read and similar drawings were grouped under the same category. Sub-categories related to the categories that produced as a result of grouping were formed and repetition frequencies ( $f$ ) and percentages
(\%) of these sub-categories were calculated. In order to support the categories with the drawings, the drawings that are considered to represent the relevant category best were determined. In order to provide coding reliability, Consensus / (Consensus + Disagreement) $\times 100$ (Miles \& Huberman, 1994) formula was used. Accordingly, if the calculated value is $70 \%$ and above, the codings are accepted to be reliable. The value calculated in this study was found to be $86 \%$ and was considered reliable for the study.

\section{Results}

The results were presented under the categories of "mathematics learning environment, people in mathematics learning environment, tools in mathematics learning environment, mathematical symbols in learning environment, expressions reflecting emotions while learning mathematics, and action in mathematics learning process" that were determined as a result of content analysis. Each grade level was examined separately according to the mentioned categories, and the results were presented with tables and drawings.

The findings according to the mathematics learning environment in the drawings of elementary school students were presented in Table 1.

When Table 1 is examined, it can be seen that the category of mathematics learning environment based on students' drawings consists of seven subcategories: Classroom, study room, schoolyard, nature, park, market and undefined. Accordingly, it is seen that the mathematics learning environment is the most perceived as class at all grade levels. In some class levels, learning environment was stated as schoolyard,

Table 1. Mathematics Learning Environments in Students' Drawings

\begin{tabular}{|c|c|c|c|c|c|c|c|c|c|}
\hline Category & Sub-categories & Grade level & $f$ & $\%$ & Category & Sub-categories & Grade level & $f$ & $\%$ \\
\hline \multirow{16}{*}{ 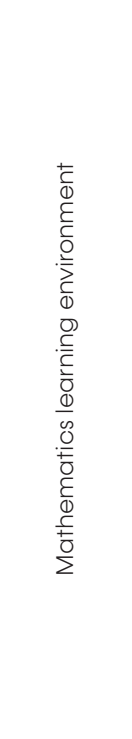 } & \multirow{4}{*}{ Classroom } & $1^{\text {st }}$ grade & 8 & 32 & \multirow{16}{*}{ 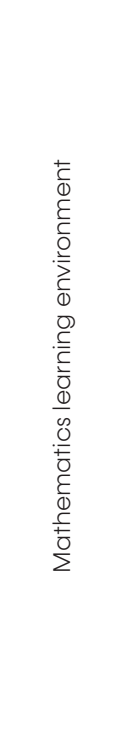 } & \multirow{4}{*}{ Classroom } & $1^{\text {st }}$ grade & - & - \\
\hline & & $2^{\text {nd }}$ grade & 71 & 65.13 & & & $2^{\text {nd }}$ grade & - & - \\
\hline & & $3^{\text {rd }}$ grade & 63 & 73.25 & & & $3^{\text {rd }}$ grade & - & - \\
\hline & & $4^{\text {th }}$ grade & 69 & 65.09 & & & $4^{\text {th }}$ grade & 1 & 0.94 \\
\hline & \multirow{4}{*}{ Study room } & $1^{\text {st }}$ grade & - & - & & \multirow{4}{*}{ Market } & $1^{\text {st }}$ grade & - & \\
\hline & & $2^{\text {nd }}$ grade & 4 & 3.66 & & & $2^{\text {nd }}$ grade & 1 & 0.91 \\
\hline & & $3^{\text {rd }}$ grade & - & - & & & $3^{\text {rd }}$ grade & - & - \\
\hline & & $4^{\text {th }}$ grade & 3 & 2.83 & & & $4^{\text {th }}$ grade & - & - \\
\hline & \multirow{4}{*}{ Schoolyard } & $1^{\text {st }}$ grade & 2 & 8 & & \multirow{4}{*}{ Undefined } & $1^{\text {st }}$ grade & 15 & 60 \\
\hline & & $2^{\text {nd }}$ grade & 6 & 5.50 & & & $2^{\text {nd }}$ grade & 23 & 21.10 \\
\hline & & $3^{\text {rd }}$ grade & - & - & & & $3^{\text {rd }}$ grade & 23 & 26.74 \\
\hline & & $4^{\text {th }}$ grade & - & - & & & $4^{\text {th }}$ grade & 29 & 27.35 \\
\hline & \multirow{4}{*}{ Nature } & $1^{\text {st }}$ grade & - & - & & & & & \\
\hline & & $2^{\text {nd }}$ grade & 4 & 3.66 & & & & & \\
\hline & & $3^{\text {rd }}$ grade & - & - & & & & & \\
\hline & & $4^{\text {th }}$ grade & 4 & 3.77 & & & & & \\
\hline
\end{tabular}




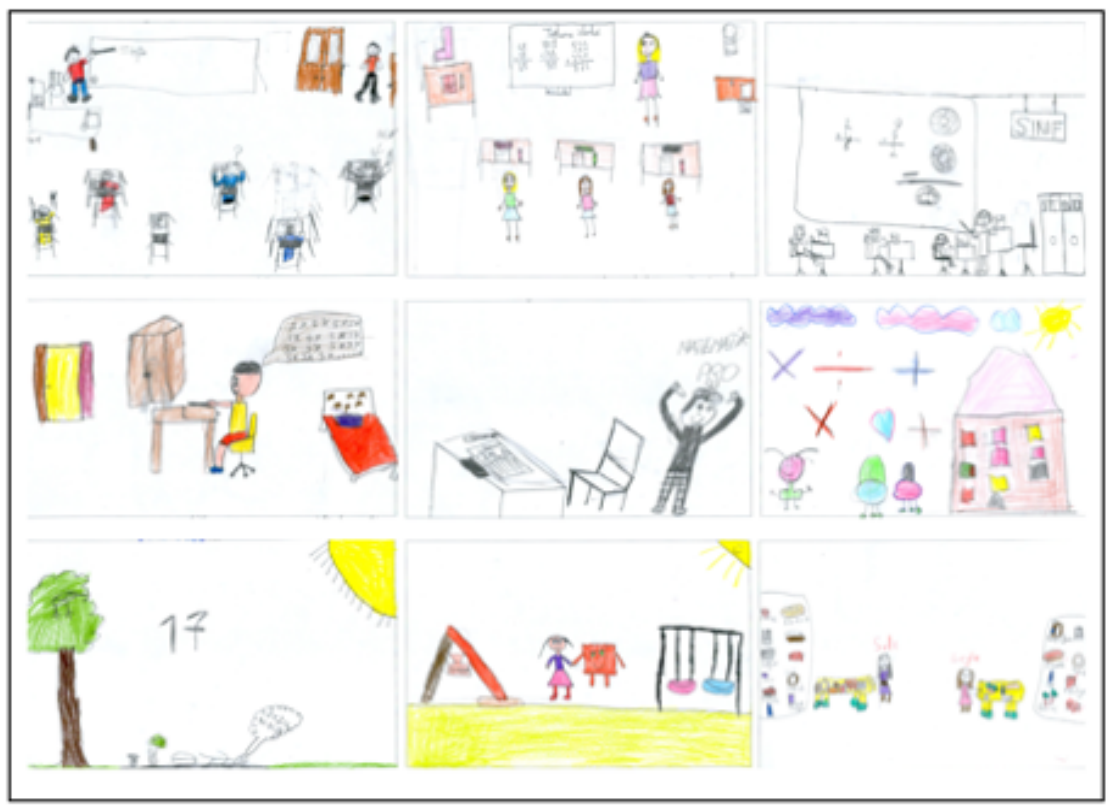

Figure 1. Sample Drawings Related to the Category of Mathematics Learning Environment

nature, and study room, while park and market are the least expressed environments. In addition, no information about the learning environment was included in the drawings or expressions of the students in each grade level. Examples of drawings of elementary school students related to the category of mathematics learning environment were presented in Figure 1.

Figure 1 shows some examples of students' drawings related to sub-categories of mathematics learning environment. While the students were explaining their drawings, there are mostly such expressions as "the classroom came to my mind", "this is my classroom", "I drew a mathematics lesson in the classroom", "we are solving the mathematical problem in the classroom", "our teacher is teaching the math in the classroom", "I drew my teacher to teach the mathematics in the classroom". In addition, there are a few expressions such as "I am studying mathematics in my room", "mathematics in the schoolyard", "I am discovering mathematics in nature", "I am playing games in the park with the square", "I spend money in the market and I am calculating".

The results of the people in the mathematics learning environment in the drawings of elementary school students were presented in Table 2.

When Table 2 is examined, the category of people in the mathematics learning environment based on the drawings of the students consists of seven

Table 2. People in Mathematics Learning Environment in Students' Drawing

\begin{tabular}{|c|c|c|c|c|c|c|c|c|c|}
\hline Category & Sub-categories & Grade level & $f$ & $\%$ & Category & Sub-categories & Grade level & $f$ & $\%$ \\
\hline \multirow{16}{*}{ 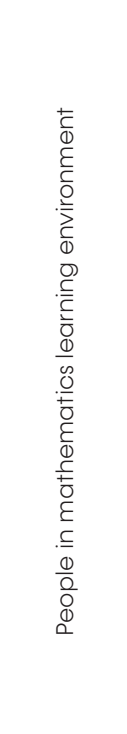 } & \multirow{4}{*}{ Only oneself } & $1^{\text {st }}$ grade & 11 & 44 & \multirow{16}{*}{ 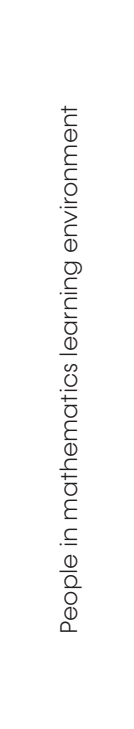 } & \multirow{4}{*}{ Mother and child } & $1^{\text {st }}$ grade & - & - \\
\hline & & $2^{\text {nd }}$ grade & 21 & 19.26 & & & $2^{\text {nd }}$ grade & 1 & 0.91 \\
\hline & & $3^{\text {rd }}$ grade & 21 & $24 . .41$ & & & $3^{\text {rd }}$ grade & - & - \\
\hline & & $4^{\text {th }}$ grade & 43 & 40.56 & & & $4^{\text {th }}$ grade & - & - \\
\hline & \multirow{4}{*}{ Only teacher } & $1^{\text {st }}$ grade & - & - & & \multirow{4}{*}{ Angle man } & $1^{\text {st }}$ grade & - & - \\
\hline & & $2^{\text {nd }}$ grade & 8 & 7.33 & & & $2^{\text {nd }}$ grade & - & - \\
\hline & & $3^{\text {rd }}$ grade & 2 & 2.32 & & & $3^{\text {rd }}$ grade & - & - \\
\hline & & $4^{\text {th }}$ grade & 4 & 3.77 & & & $4^{\text {th }}$ grade & 2 & 1.88 \\
\hline & \multirow{4}{*}{ Students } & $1^{\text {st }}$ grade & 9 & 36 & & \multirow{4}{*}{ No one } & $1^{\text {st }}$ grade & 4 & 16 \\
\hline & & $2^{\text {nd }}$ grade & 24 & 22.01 & & & $2^{\text {nd }}$ grade & 17 & 15.59 \\
\hline & & $3^{\text {rd }}$ grade & 7 & 8.13 & & & $3^{\text {rd }}$ grade & 20 & 23.25 \\
\hline & & $4^{\text {th }}$ grade & 12 & 11.32 & & & $4^{\text {th }}$ grade & 21 & 19.81 \\
\hline & \multirow{4}{*}{ Teacher and student(s) } & $1^{\text {st }}$ grade & 1 & 4 & & & & & \\
\hline & & $2^{\text {nd }}$ grade & 38 & 41.86 & & & & & \\
\hline & & $3^{\text {rd }}$ grade & 36 & 41.86 & & & & & \\
\hline & & $4^{\text {th }}$ grade & 24 & 22.64 & & & & & \\
\hline
\end{tabular}




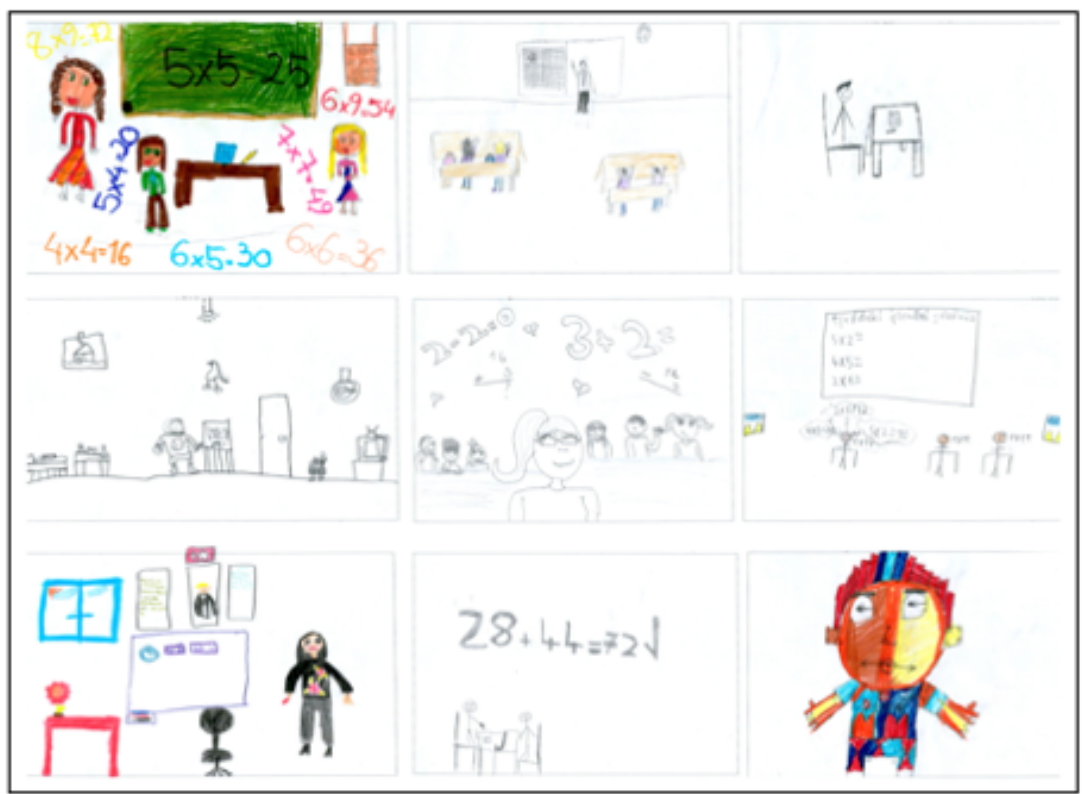

Figure 2. Sample Drawings Related to the People in Mathematics Learning Environment

sub-categories: only oneself, only teacher, students, teacher and student(s), mother and child, angle man and no one. According to this, despite the differences in terms of grade levels, it is seen that people in the mathematics learning environment are generally perceived as teacher and student(s), only oneself, students and only teachers. People in the learning environment were expressed as mother and child at one grade level and "angle man" at one grade level. Besides, people in the learning environment were not expressed in the drawings or expressions of the students in each grade level. Sample drawings of elementary school students related to the category of people in the mathematics learning environment were presented in Figure 2.

In Figure 2, sample drawings of students related to the subcategories in the category of people in mathematics learning environment were presented.
While the students were explaining their drawings, they mostly included statements such as "the teacher is teaching us mathematics", "the teacher is waiting, the children are thinking about the answer", "the teacher is waiting, we are writing the questions on the board", "the teacher called me to the board", "we are applauding our friend who solved the question correctly". In addition to this, there are a few expressions such as "I am doing mathematics homework alone at home", "a mother is teaching mathematics to her child", "the man is showing angles".

Table 3 shows the results related to tools in mathematics learning environment in students' drawing.

When Table 3 is examined, the category of tools in mathematics learning environment based on students' drawings consists of eight sub-categories: General

Table 3. Tools in Mathematics Learning Environment in Students' Drawings

\begin{tabular}{|c|c|c|c|c|c|c|c|c|c|}
\hline Category & Sub-categories & Grade level & $f$ & $\%$ & Category & Sub-categories & Grade level & $f$ & $\%$ \\
\hline \multirow{16}{*}{ 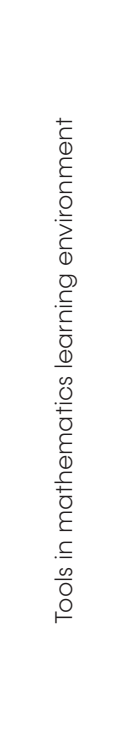 } & \multirow{4}{*}{$\begin{array}{c}\text { General items in } \\
\text { classroom environ- } \\
\text { ment }\end{array}$} & $1^{\text {st }}$ grade & 8 & 32 & \multirow{16}{*}{ 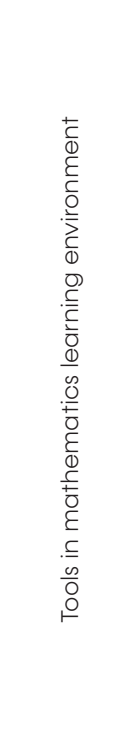 } & \multirow{4}{*}{ 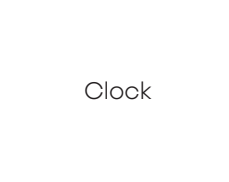 } & $1^{\text {st }}$ grade & 1 & 4 \\
\hline & & $2^{\text {nd }}$ grade & 82 & 75.22 & & & $2^{\text {nd }}$ grade & 3 & 2.75 \\
\hline & & $3^{\text {rd }}$ grade & 71 & 82.55 & & & $3^{\text {rd }}$ grade & - & - \\
\hline & & $4^{\text {th }}$ grade & 70 & 66.03 & & & $4^{\text {th }}$ grade & - & - \\
\hline & \multirow{4}{*}{ Swing } & $1^{\text {st }}$ grade & - & - & & \multirow{4}{*}{$\begin{array}{l}\text { Measurement and } \\
\text { drawing materials }\end{array}$} & $1^{\text {st }}$ grade & - & - \\
\hline & & $2^{\text {nd }}$ grade & - & - & & & $2^{\text {nd }}$ grade & - & - \\
\hline & & $3^{\text {rd }}$ grade & - & - & & & $3^{\text {rd }}$ grade & - & - \\
\hline & & $4^{\text {th }}$ grade & 1 & 0.94 & & & $4^{\text {th }}$ grade & 3 & 2.83 \\
\hline & \multirow{4}{*}{ Machine-robot } & $1^{\text {st }}$ grade & - & - & & \multirow{4}{*}{ Grocery cart } & $1^{\text {st }}$ grade & - & - \\
\hline & & $2^{\text {nd }}$ grade & 1 & 0.91 & & & $2^{\text {nd }}$ grade & 1 & 0.91 \\
\hline & & $3^{\text {rd }}$ grade & 1 & 1.16 & & & $3^{\text {rd }}$ grade & - & - \\
\hline & & $4^{\text {th }}$ grade & 1 & 0.94 & & & $4^{\text {th }}$ grade & - & - \\
\hline & \multirow{4}{*}{ Smart board } & $1^{\text {st }}$ grade & - & - & & \multirow{4}{*}{ No tools } & $1^{\text {st }}$ grade & 16 & 64 \\
\hline & & $2^{\text {nd }}$ grade & 1 & 0.91 & & & $2^{\text {nd }}$ grade & 21 & 19.26 \\
\hline & & $3^{\text {rd }}$ grade & - & - & & & $3^{\text {rd }}$ grade & 14 & 16.27 \\
\hline & & $4^{\text {th }}$ grade & 1 & 0.94 & & & $4^{\text {th }}$ grade & 30 & 28.30 \\
\hline
\end{tabular}




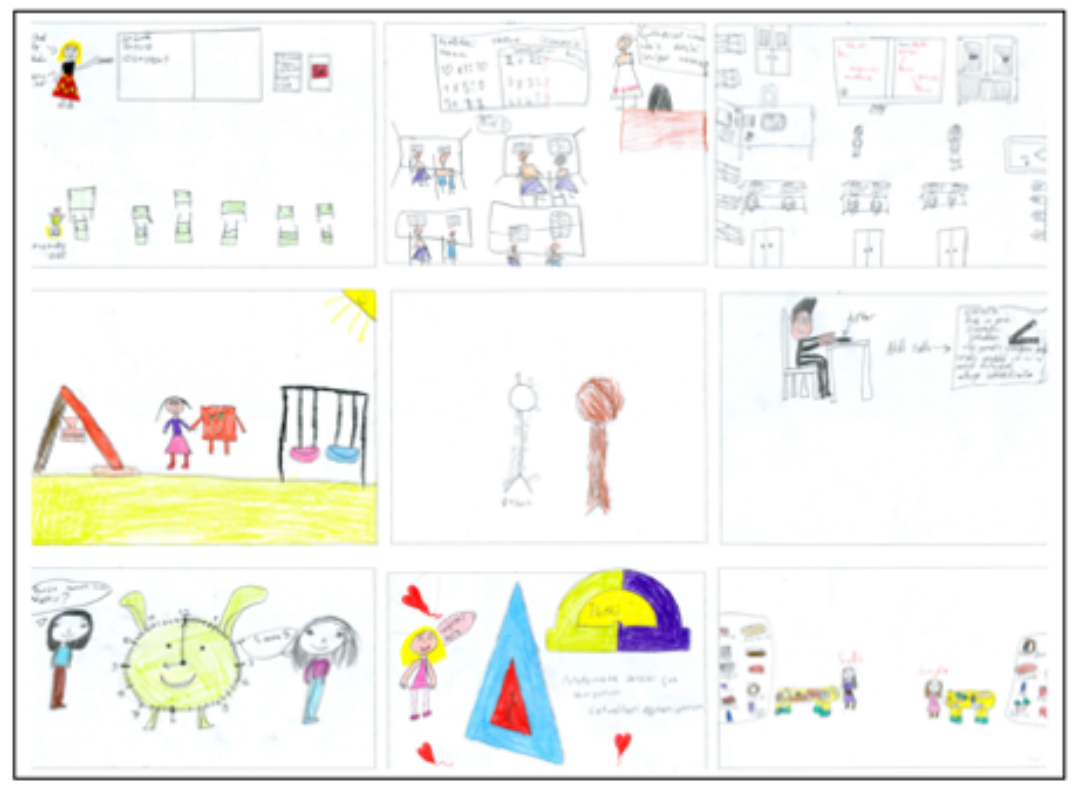

Figure 3. Sample Drawings Related to the Tools in Mathematics Learning Environment

items in the classroom environment (books, notebooks, pens, paper, table, desk, chair, board, bookcase), swing, machine-robot, smart board, clock, measurement and drawing materials (miter, protractor, ruler), grocery cart. Accordingly, it is seen that tools in mathematics learning environment are perceived as general items in the classroom environment at all grade levels. Additionally, different grade levels, a small number of tools such as swing, machine-robot, smart board, clock, measurement and drawing materials, grocery cart were also expressed. In addition, no information about the tools in mathematics learning environment was included in the drawings or expressions of the students at each grade level. Sample drawings of elementary school students related to the category of tools in mathematics learning environment were presented in Figure 3.
In Figure 3, sample drawings related to the subcategories of tools in mathematics learning environment were presented. It is seen that most of the drawings include general items in the classroom environment (books, notebooks, pens, paper, tables, desks, chairs, wood, bookshelves). While students explain their drawings, they mostly wrote sentences such as "I am writing the result of the operation in my notebook", "I am drawing the shape of my notebook", "I am doing an operation on the board", "I went to the board and did all the operations", "we are writing the things on the board in our notebook", "we are sitting quietly in our desks, listening to our teacher", and I took out my Maths coursebook and notebook ", "I am using coloured pencil to draw the shapes". In addition to this, there are a few different expressions such as "I made operation on the smart board", "I made a robot with

Table 4. Mathematical Symbols in Mathematics Learning Environment in Students' Drawing

\begin{tabular}{|c|c|c|c|c|c|c|c|c|c|}
\hline Category & Sub-categories & Grade level & $f$ & $\%$ & Category & Sub-categories & Grade level & $f$ & $\%$ \\
\hline \multirow{16}{*}{ 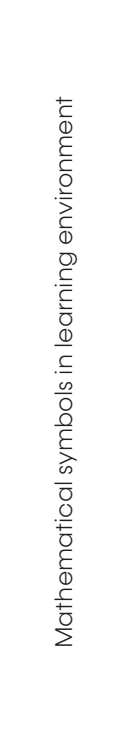 } & \multirow{4}{*}{$\begin{array}{l}\text { Numeral-number-four } \\
\text { operation symbols }\end{array}$} & $1^{\text {st }}$ grade & 13 & 52 & \multirow{16}{*}{ 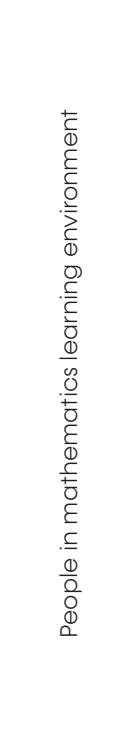 } & \multirow{4}{*}{$\begin{array}{c}\text { Geometric figure } \\
\text {-object }\end{array}$} & $1^{\text {st }}$ grade & - & - \\
\hline & & $2^{\text {nd }}$ grade & 93 & 85.32 & & & $2^{\text {nd }}$ grade & - & - \\
\hline & & $3^{\text {rd }}$ grade & 52 & 60.46 & & & $3^{\text {rd }}$ grade & 8 & 9.30 \\
\hline & & $4^{\text {th }}$ grade & 50 & 47.16 & & & $4^{\text {th }}$ grade & 4 & 3.77 \\
\hline & \multirow{4}{*}{ Number-count } & $1^{\text {st }}$ grade & - & - & & \multirow{4}{*}{$\begin{array}{l}\text { Letters- four opera- } \\
\text { tion symbol }\end{array}$} & $1^{\text {st }}$ grade & - & - \\
\hline & & $2^{\text {nd }}$ grade & - & - & & & $2^{\text {nd }}$ grade & - & - \\
\hline & & $3^{\text {rd }}$ grade & - & - & & & $3^{\text {rd }}$ grade & - & - \\
\hline & & $4^{\text {th }}$ grade & 9 & 8.49 & & & $4^{\text {th }}$ grade & 2 & 1.88 \\
\hline & \multirow{4}{*}{ Angel } & $1^{\text {st }}$ grade & - & - & & \multirow{4}{*}{ Measure of length } & $1^{\text {st }}$ grade & - & - \\
\hline & & $2^{\text {nd }}$ grade & - & - & & & $2^{\text {nd }}$ grade & - & - \\
\hline & & $3^{\text {rd }}$ grade & - & - & & & $3^{\text {rd }}$ grade & - & - \\
\hline & & $4^{\text {th }}$ grade & 15 & 14.15 & & & $4^{\text {th }}$ grade & 3 & 2.83 \\
\hline & \multirow{4}{*}{ Fraction } & $1^{\text {st }}$ grade & - & - & & \multirow{4}{*}{ No symbols } & $1^{\text {st }}$ grade & 12 & 48 \\
\hline & & $2^{\text {nd }}$ grade & - & - & & & $2^{\text {nd }}$ grade & 16 & 14.67 \\
\hline & & $3^{\text {rd }}$ grade & 1 & 1.16 & & & $3^{\text {rd }}$ grade & 25 & 29.06 \\
\hline & & $4^{\text {th }}$ grade & 6 & 5.66 & & & $4^{\text {th }}$ grade & 17 & 16.03 \\
\hline
\end{tabular}




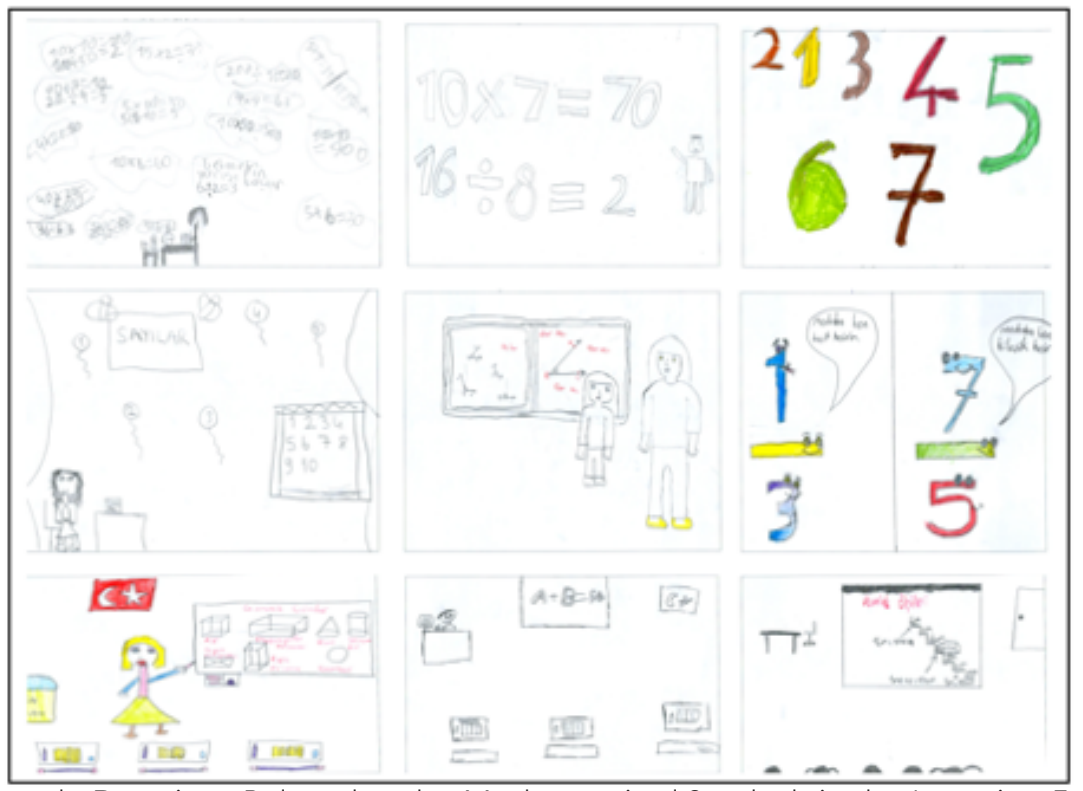

Figure 4. Sample Drawings Related to the Mathematical Symbols in the Learning Environment

geometric objects", "I am riding on the swing while doing an operation", "wow, huge protractor", "I draw a clock", "I am putting my purchases in the shopping cart".

The results related to the mathematical symbols in mathematics learning environment in the drawings of elementary school students were presented in Table 4.

When Table 4 is examined, the category of mathematical symbols in the learning environment based on students' drawings consists of eight subcategories: numeral-number-four operation symbols, number-count, angle, fraction, geometric figureobject, letters-four operation symbol, measure of length and no symbols. Accordingly, the numeralnumber-four operation symbols were most included in the drawings at all grade levels. In addition, numberscount, angles, fractions, geometric figures-objects, letters-four operation symbols and measure of length were included in the drawings of different grade levels. In addition, no mathematical symbols and no statements explaining the drawings were expressed in the learning environment in each grade level. Sample drawings of elementary school students related the mathematical symbols in the learning environment were presented in Figure 4.

Figure 4 shows sample drawings related to the subcategories of mathematical symbols in the learning environment. While students were explaining their drawings, they mostly included expressions such as "I am playing with numbers", "numbers and signs are coming to my mind", "I am creating numbers from counts", "I am in the world of numbers", "I drew multiplication and division signs", "I made a huge plus sign". In addition to this, there are different expressions such as "there are angles in mathematics", "I drew simple and compound fractions", "I drew geometric objects on the board", "A + B = 54", "I wrote measurements of length".

The findings related to the expressions reflecting emotions while learning mathematics in the drawings of elementary school students are presented in Table 5.

Table 5. Expressions Reflecting Emotions While Learning Mathematics in Students' Drawings

\begin{tabular}{|c|c|c|c|c|}
\hline Category & Sub-categories & Grade level & $f$ & $\%$ \\
\hline \multirow{12}{*}{ Expressions reflecting emotions while learning mathematics } & \multirow{4}{*}{ Happy-enjoyable-fun } & $1^{\text {st }}$ grade & 8 & 32 \\
\hline & & $2^{\text {nd }}$ grade & 82 & 75.22 \\
\hline & & $3^{\text {rd }}$ grade & 71 & 82.55 \\
\hline & & $4^{\text {th }}$ grade & 70 & 66.03 \\
\hline & \multirow{4}{*}{ Bored-anxious } & $1^{\text {st }}$ grade & - & - \\
\hline & & $2^{\text {nd }}$ grade & - & - \\
\hline & & $3^{\text {rd }}$ grade & - & - \\
\hline & & $4^{\text {th }}$ grade & 1 & 0.94 \\
\hline & \multirow{4}{*}{ Undefined } & $1^{\text {st }}$ grade & - & - \\
\hline & & $2^{\text {nd }}$ grade & 1 & 0.91 \\
\hline & & $3^{\text {rd }}$ grade & 1 & 1.16 \\
\hline & & $4^{\text {th }}$ grade & 1 & 0.94 \\
\hline
\end{tabular}




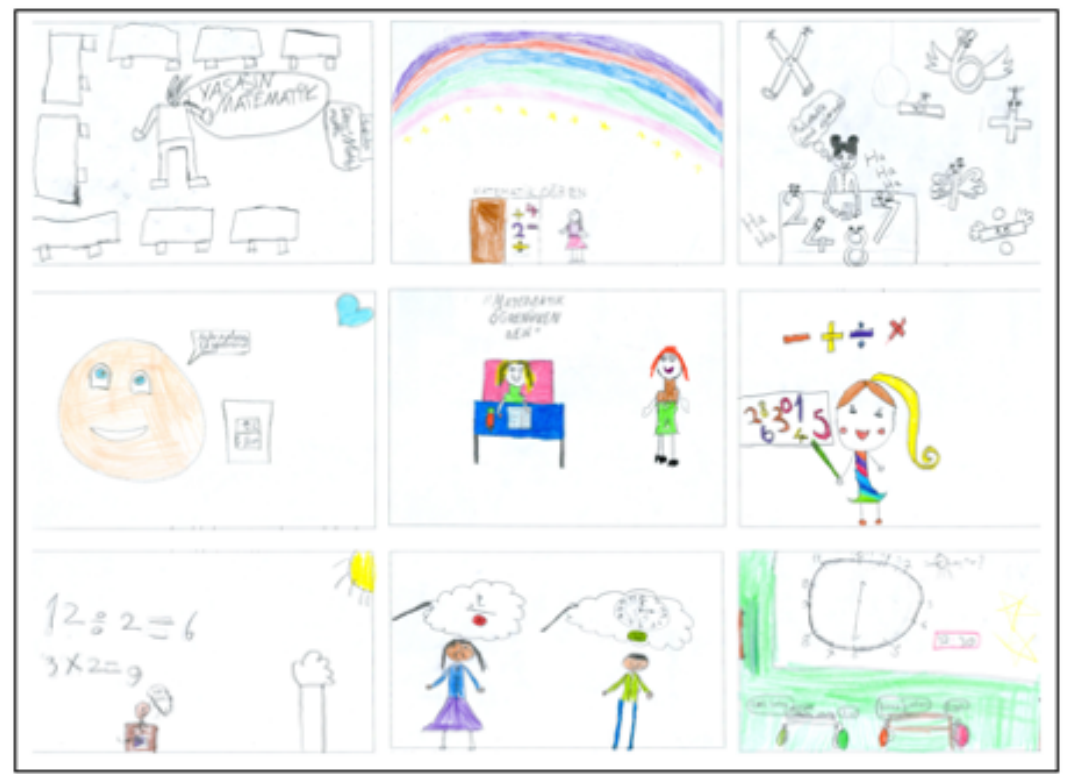

Figure 5. Sample Drawings Related to the Expressions Reflecting Emotions While Learning Mathematics

When Table 5 is examined, the expressions reflecting emotions while learning mathematics based on students' drawings consist of three sub-categories: happy-enjoyable-fun, bored-anxious and no symbols. Accordingly, learning mathematics at all grade levels is generally perceived as happy-enjoyable-fun. However, emotions while learning mathematics were less expressed as bored-anxious in different grade levels. In addition, no expressions reflecting emotions while learning mathematics were included in the drawings in each grade level. Sample drawings of elementary school students related to the expressions reflecting emotions while learning mathematics were presented in Figure 5.

In Figure 5, sample drawings related to subcategories of expressions reflecting emotions while learning mathematics were presented. While students explained their drawings, they mostly included expressions such as "learning mathematics is good", "mathematics means having fun", "I am happy while learning mathematics", "I love mathematics", "long live mathematics". In addition, there are different expressions such as "I cannot say anything in case the teacher gets angry", "I think the answer to the question is correct", "There are difficult questions", "I am very tired in the mathematics lesson", "It is difficult for those who cannot do it, it is easy for those who can do it".

The results related to the action in the mathematics learning process in the drawings of elementary school students were presented in Table 6.

When Table 6 is examined, the category of action in the mathematics learning process based on the

Table 6. Action in Mathematics Learning Process in Students' Drawings

\begin{tabular}{|c|c|c|c|c|c|c|c|c|c|}
\hline Category & Sub-categories & Grade level & $f$ & $\%$ & Category & Sub-categories & Grade level & $f$ & $\%$ \\
\hline \multirow{16}{*}{ 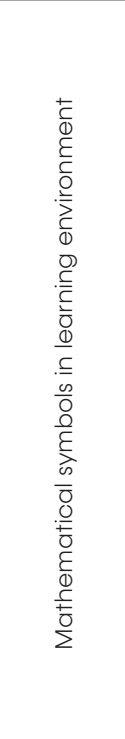 } & \multirow{4}{*}{ Doing-learning addition } & $1^{\text {st }}$ grade & 7 & 28 & \multirow{16}{*}{ 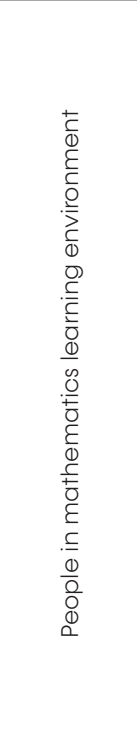 } & \multirow{4}{*}{ Solving problems } & $1^{\text {st }}$ grade & 7 & 28 \\
\hline & & $2^{\text {nd }}$ grade & 10 & 9.17 & & & $2^{\text {nd }}$ grade & 10 & 9.17 \\
\hline & & $3^{\text {rd }}$ grade & 8 & 9.30 & & & $3^{\text {rd }}$ grade & 8 & 9.30 \\
\hline & & $4^{\text {th }}$ grade & 2 & 1.83 & & & $4^{\text {th }}$ grade & 2 & 1.83 \\
\hline & \multirow{4}{*}{$\begin{array}{l}\text { Doing-learning } \\
\text { subtraction }\end{array}$} & $1^{\text {st }}$ grade & - & - & & \multirow{4}{*}{$\begin{array}{l}\text { Listening to the } \\
\text { lesson Taught by } \\
\text { the teacher }\end{array}$} & $1^{\text {st }}$ grade & - & - \\
\hline & & $2^{\text {nd }}$ grade & 2 & 1.83 & & & $2^{\text {nd }}$ grade & 2 & 1.83 \\
\hline & & $3^{\text {rd }}$ grade & 1 & 1.16 & & & $3^{\text {rd }}$ grade & 1 & 1.16 \\
\hline & & $4^{\text {th }}$ grade & 1 & 0.91 & & & $4^{\text {th }}$ grade & 1 & 0.91 \\
\hline & \multirow{4}{*}{$\begin{array}{l}\text { Doing-learning } \\
\text { multiplication }\end{array}$} & $1^{\text {st }}$ grade & - & - & & \multirow{4}{*}{$\begin{array}{l}\text { Learning the } \\
\text { subject of sym- } \\
\text { metry }\end{array}$} & $1^{\text {st }}$ grade & - & - \\
\hline & & $2^{\text {nd }}$ grade & 25 & 22.93 & & & $2^{\text {nd }}$ grade & 25 & 22.93 \\
\hline & & $3^{\text {rd }}$ grade & 21 & 24.41 & & & $3^{\text {rd }}$ grade & 21 & 24.41 \\
\hline & & $4^{\text {th }}$ grade & 23 & 21.10 & & & $4^{\text {th }}$ grade & 23 & 21.10 \\
\hline & \multirow{4}{*}{ Doing-learning division } & $1^{\text {st }}$ grade & - & - & & \multirow{4}{*}{$\begin{array}{c}\text { Doing } \\
\text { addition- } \\
\text { subtraction from } \\
\text { mind }\end{array}$} & $1^{\text {st }}$ grade & - & - \\
\hline & & $2^{\text {nd }}$ grade & 6 & 5.50 & & & $2^{\text {nd }}$ grade & 6 & 5.50 \\
\hline & & $3^{\text {rd }}$ grade & 5 & 5.81 & & & $3^{\text {rd }}$ grade & 5 & 5.81 \\
\hline & & $4^{\text {th }}$ grade & 9 & 8.25 & & & $4^{\text {th }}$ grade & 9 & 8.25 \\
\hline
\end{tabular}


Table 6 (Cont.). Action in Mathematics Learning Process in Students' Drawings

\begin{tabular}{|c|c|c|c|c|c|c|c|c|c|}
\hline Category & Sub-categories & Grade level & $f$ & $\%$ & Category & Sub-categories & Grade level & $f$ & $\%$ \\
\hline \multirow{20}{*}{ 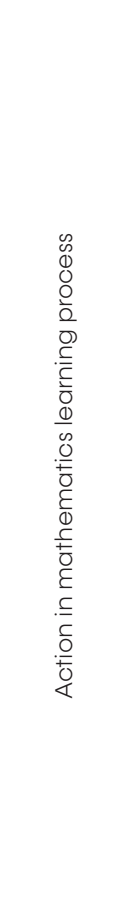 } & \multirow{4}{*}{ Learning fractions } & $1^{\text {st }}$ grade & - & - & \multirow{20}{*}{ 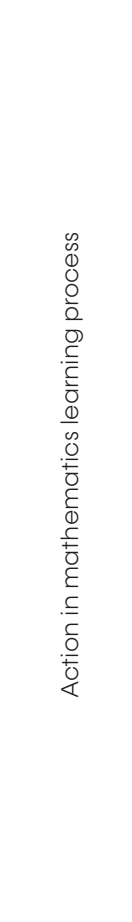 } & \multirow{4}{*}{ Learning hours } & $1^{\text {st }}$ grade & 1 & 4 \\
\hline & & $2^{\text {nd }}$ grade & - & - & & & $2^{\text {nd }}$ grade & 7 & 6.42 \\
\hline & & $3^{\text {rd }}$ grade & - & - & & & $3^{\text {rd }}$ grade & - & - \\
\hline & & $4^{\text {th }}$ grade & 5 & 4.58 & & & $4^{\text {th }}$ grade & - & - \\
\hline & \multirow{4}{*}{ Learning angles } & $1^{\text {st }}$ grade & - & - & & \multirow{4}{*}{$\begin{array}{l}\text { Spending money } \\
\text { and calculating }\end{array}$} & $1^{\text {st }}$ grade & - & - \\
\hline & & $2^{\text {nd }}$ grade & - & - & & & $2^{\text {nd }}$ grade & 1 & 0.91 \\
\hline & & $3^{\text {rd }}$ grade & - & - & & & $3^{\text {rd }}$ grade & - & - \\
\hline & & $4^{\text {th }}$ grade & 12 & 11 & & & $4^{\text {th }}$ grade & - & - \\
\hline & \multirow{4}{*}{$\begin{array}{l}\text { Learning geometric } \\
\text { figures and objects }\end{array}$} & $1^{\text {st }}$ grade & - & - & & \multirow{4}{*}{$\begin{array}{l}\text { Round up to dec- } \\
\text { imal }\end{array}$} & $1^{\text {st }}$ grade & - & - \\
\hline & & $2^{\text {nd }}$ grade & - & - & & & $2^{\text {nd }}$ grade & - & - \\
\hline & & $3^{\text {rd }}$ grade & 5 & 5.81 & & & $3^{\text {rd }}$ grade & 1 & 1.16 \\
\hline & & $4^{\text {th }}$ grade & 1 & 0.91 & & & $4^{\text {th }}$ grade & - & - \\
\hline & \multirow{4}{*}{$\begin{array}{l}\text { Learning measurement } \\
\text { of length and girth }\end{array}$} & $1^{\text {st }}$ grade & - & - & & \multirow{4}{*}{ Undefined } & $1^{\text {st }}$ grade & 15 & 60 \\
\hline & & $2^{\text {nd }}$ grade & - & - & & & $2^{\text {nd }}$ grade & 28 & 25.68 \\
\hline & & $3^{\text {rd }}$ grade & - & - & & & $3^{\text {rd }}$ grade & 22 & 25.58 \\
\hline & & $4^{\text {th }}$ grade & 1 & 0.91 & & & $4^{\text {th }}$ grade & 43 & 39.44 \\
\hline & \multirow{4}{*}{$\begin{array}{l}\text { Doing mathematics } \\
\text { homework }\end{array}$} & $1^{\text {st }}$ grade & - & - & & & & & \\
\hline & & $2^{\text {nd }}$ grade & 4 & 3.66 & & & & & \\
\hline & & $3^{\text {rd }}$ grade & - & - & & & & & \\
\hline & & $4^{\text {th }}$ grade & 1 & 0.91 & & & & & \\
\hline
\end{tabular}

drawings of the students consists of seventeen subcategories: doing-learning addition, doing-learning subtraction, doing-learning multiplication, doinglearning division, learning fractions, learning angles, learning geometric figures and objects, learning measure of length and girth, doing math homework, solving problems, listening to the class taught by the teacher, learning the subject of symmetry, adding and subtracting from the mind, learning hours, spending money-calculating, rolling to decimal and undefined.
Accordingly, despite some differences in terms of grade levels, it is seen that the actions of doinglearning multiplication, doing-learning addition, and listening to the lesson taught by the teacher stand out in the mathematics learning process. In addition, no actions related to the mathematics learning process were expressed in the drawings at each grade level. Sample drawings of elementary school students related to the action in the mathematics learning process were presented in Figure 6.

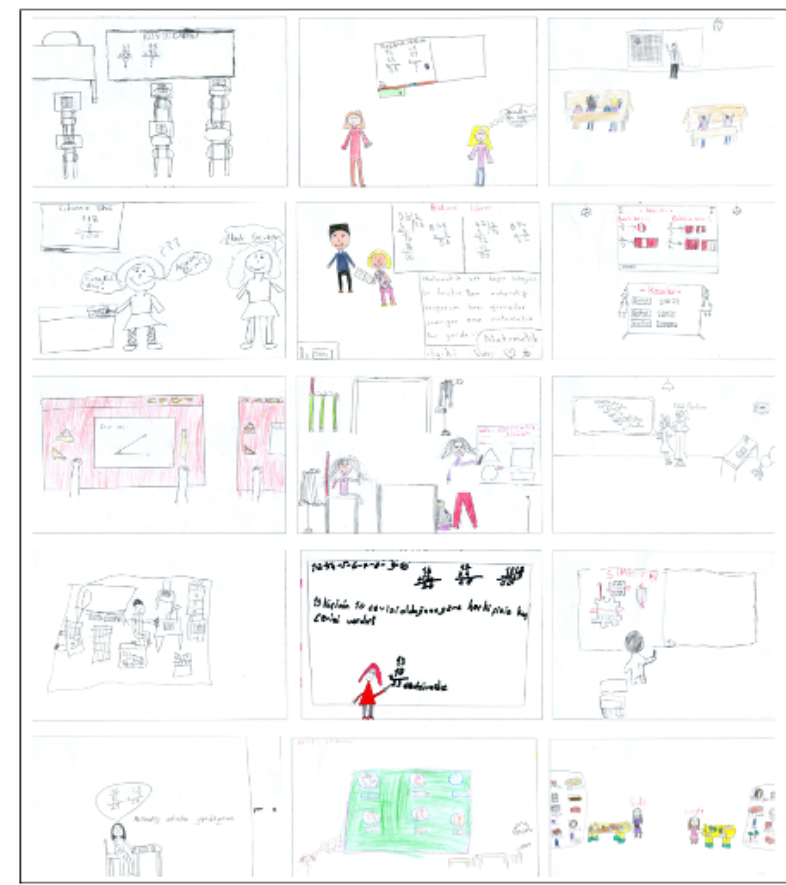

Figure 6. Sample Drawings Related to the Action in the Mathematics Learning Process 
In Figure 6, sample drawings related to sub-categories of action category in mathematics learning process were presented. When students explained their drawings, the most expressed statements are "mathematics means multiplication", "I draw myself while doing multiplication", "I am doing multiplication on the board", "ourteacher is teaching us multiplication", "we are learning addition operation", "the subject is addition operation", "mathematics is addition", "our teacher is teaching the subject", "our teacher is doing an operation on the board", "our teacher is asking questions". In addition, a small number of statements were expressed: "I am solving the problem on the board", "I am measuring the angle", "I am drawing the axis of symmetry", "our teacher is teaching fractions", "I am spending money and calculating in the market", "I am learning geometric objects", "I am doing addition and subtraction from the mind". There are different expressions such as "I do the process", "our teacher is teaching us measurements of length".

\section{Discussion and Conclusion}

In this research, which aims to examine the perceptions of elementary school students towards learning mathematics by means of their drawings, students' drawings were described in six subcategories: "mathematics learning environment, people in mathematics learning environment, tools in mathematics learning environment, mathematical symbols in learning environment, expressions reflecting emotions while learning mathematics, and action in mathematics learning process".

According to the research results, it is seen that the mathematics learning environment is mostly perceived as labeled under the subcategory "classroom" at all grade levels. Similarly, in Picker and Berry's (2000) research which examined the mathematic perceptions of secondary school students, the drawings included a schoolteacher and classroom descriptions. Classroom is an environment where elementary school students spend most of their time during education and accordingly, their perceptions about education are shaped during this period. In a properly structured classroom learning environment, students begin to regard mathematics as logical, valuable, and useful over time. When this positive trend towards mathematics is combined with students' individual efforts and own efficacy, a classroom can be the third teacher (Kilpatrick et al., 2001). However, mathematics teaching should be carried out not only in the classroom but also in non-classroom settings. For example, as a result of this research, a small number of schoolyard (8 students), nature (8 students), park (1 student) and market (1 student) were expressed as mathematics learning environment. Non-classroom environments can develop a positive attitude towards mathematics and more motivation in students, by allowing them to realize the applicability of mathematics (Barbosa \& Vale, 2016). Students have the opportunity to use and apply the mathematics they learned in the classroom in real life. In this way, they realize the value of mathematics as daily life skills with real experiences. They can create a solid foundation for knowledge and understanding of the world around them in mathematics (Kennard, 2007). Education by means of activities in the natural environment makes the subject fields interesting and easier to understand (Bunting, 2006). Such activities facilitate the creation of an informal meeting space that encourages problem solving, connecting, promoting communication, and the application of other mathematical skills in a meaningful context (Richardson, 2004). Learning mathematics through open-air experiences such as museum visits which includes mathematical exhibitions and a series of outdoor games where players need to perform certain tasks using mathematics offers different alternatives to teachers and students (Ho, 2008). Masingila, Davidenko and Wisniowska (1996), Fägerstam and Blom (2013) stated that there is a potential positive relationship between non-classroom activities and their mathematics skills and competences. Therefore, it can be stated that it is necessary to ensure that students encounter non-classroom mathematical activities in elementary school, and that teachers are provided with the necessary opportunities in schools; and perhaps, teachers should be trained on this subject.

According to the research results, although there are some differences in terms of grade levels, it is seen that people in the mathematics learning environment are generally perceived as teachers and student(s), only oneself, students and only teachers. The statements which the students explained their drawings about the people in the mathematics learning environment shows that the teacher mostly instruct the subject and the students listen, and write the things written on the board in their notebooks. This indicates that the teacher is at the forefront in the learning environment. Students' understanding of mathematics, their ability to use mathematics and their self-confidence are shaped by the instruction at school. Students should learn mathematics by understanding and actively developing new knowledge through experience and prior knowledge (NCTM, 2000). Successful learning takes place in student-centered environment in which the focus is on the knowledge, skills, attitudes and beliefs that students bring to the educational environment; in knowledge-centered focusing on what to teach, what is taught, and doing by understanding, in assessment-centered learning environments focusing on providing opportunities to make students' thinking and learning visible and 
in a community-centered learning environment encouraging a culture of questioning, respect and risktaking (Donovan \& Bransford, 2005). For this, teachers need to create learning environments that support student participation (Bransford, Brown, \& Cocking, 2000).

According to the research results, it is seen that the tools and materials in the mathematics learning environment at all grade levels are mostly perceived as general items (books, notebooks, pencils, paper, tables, desks, chairs, boards, bookshelves) in the classroom. This result indicates that teaching mathematics is carried out more traditionally. The most important role of teachers in the learning process of students is to determine activities, organize the learning environment and use technology effectively (NCTM, 2000). Technology, visual and physical models, manipulatives, and spending time on visualization enable students to access a wider mathematical experience (Holton et al., 2009). The purpose of using such tools is to demonstrate mathematical ideas and build mathematical understanding (Bahr \& de Garcia, 2010). Tools are materials, models, and representations that students use to organize their thoughts and follow these organized steps while solving problems (Ernst \& Ryan, 2014). Tools provide students with valuable and interesting experiences in mathematics and offer them the opportunity to embody abstract ideas (Burns \& Silbey, 2000). They can encourage students' logical thinking, number and spatial skills, classification, sorting and grouping skills (Freiman, Kadijevich, Kuntz, Pozdnyakov, \& Stedøy, 2009). They help students create mathematical concepts and support meaningful learning (Bahr \& de Garcia, 2010). Moreover, it was determined that using tools increases the ability to keep knowledge in mind and problem solving (Clements \& McMillen, 1996). The use of technological tools can make it fun for students to engage in geometry, pattern, and number-perceiving activities (Holton et al., 2009). Such tools can be said to make it easier for students to learn and understand basic skills. Therefore, it can be said that elementary school teachers should use a variety of tools to help students do mathematics during mathematics teaching.

According to the research results, in terms of mathematical symbols in the learning environment, numeral-number-four operation symbols were included the most in the drawings at all grade levels. Teaching numbers and operations is the core of elementary school mathematics (Thanheiser, Whitacre, \& Roy, 2014). Most elementary school mathematics is based on the operations of addition, subtraction, multiplication and division (Freitag, 2014). Numbers form the cornerstone of the entire mathematics curriculum internationally (Reys \& Nohda, 1994). The first mathematical reasoning of young children is related to numbers, and most likely their first mathematical representation consists of numbers (Fuson, 1992). NCTM (2000, p.32) emphasizes that all students should learn numbers, ways to represent numbers, relationships between numbers and number systems, the meaning of operations and their relationships with each other, the ability to do operations fluently. The numbers in elementary mathematics program in Turkey and operations are located mainly in the fields of learning (Ministry of National Education [MoNE], 2018). Therefore, according to the results of the research, it is an expected situation to include numerical-count-four operation symbols in the student drawings. However, the learning fields of geometry, measurement and data processing (MoNE, 2018) in the elementary school mathematics program should not be ignored. NCTM (2000) emphasizes that students should understand the patterns, relationships and functions of elementary school students related to different learning fields, that they should be able to represent and analyze mathematical structures using algebraic symbols, they should be able to use models to represent numerical relationships, they should be able to make visualization while solving problems, use spatial reasoning and geometric models, they should be able to apply appropriate techniques, tools, and formulas to determine measurements, they should be able to use and select appropriate statistical methods to analyze data, and that they should be able to develop and evaluate data-based inferences and predictions. Based on this, it can be said that the relevant symbols can be created in the minds of the students by allocating enough time to the learning fields mentioned during the teaching of the elementary school teachers. According to the research findings, it is notable that there are numbers, counts, angles, fractions, geometric figures and objects, letters-four operation symbols and length measurement symbols in the drawings of different grade levels. For example, the inclusion of letters and four operation symbols in the drawings of two fourth grade students indicate the transition to algebraic thought in students.

According to the research findings, learning mathematics at all grade levels is generally perceived as happy-enjoyable-fun. Based on this, it can be stated that students' attitudes towards learning mathematics are positive. The attitude towards mathematics is expressed as "a belief in loving or not loving mathematics, participating in or avoiding mathematics activities, believing that someone is good or bad in mathematics, and that mathematics is useful or useless" (Neale, 1969, p. 632). Positive attitudes can increase students' desire to learn and make use of mathematics (Eshun, 2004). It was stated that students who have a positive attitude towards mathematics are more successful in mathematics (Nicolaidou \& Philippou, 2003; Sanchez, Zimmerman, 
\& Ye, 2004). Moreover, when students first go to school, it is stated that their attitudes towards mathematios are positive, their attitudes become less positive as the grade level gets higher and often become negative in high school (Biatchford, 1996; Nicolaidou \& Philippou, 2003). However, students' attitudes towards mathematics affect various variables including factors related to students themselves, factors related to school, teacher and education, and factors related to the home environment and society (Fraser \& Kahle, 2007; Mohamed \& Waheed, 2011). Therefore, it can be said that elementary school teachers' presenting an effective teaching to their students and creating a positive learning environment will help students develop a positive attitude towards learning mathematics.

According to the research results, despite the differences in terms of grade levels, it is seen that the actions of doing-learning multiplication and addition, and listening to the lesson taught by the teacher stand out in the math learning process. Elementary school mathematics is the beginning of mathematics education and it contains the fundamental principles of mathematical concepts and forms the basis for further learning (Ma, 1999). The basis of elementary school mathematics is arithmetic skills related to addition, subtraction, multiplication and division (Freitag, 2014; NCTM, 2000). Consequently, arithmetic operations are expected to stand out as an action in the mathematics learning process in students' drawings. However, it should be noted that learning actions towards geometry, measurement, and data processing (MoNE, 2018) learning fields in the elementary school mathematics curriculum were not included in the students' drawings. This is due to the reason that as a discipline, math learning fields are interconnected. For example, numbers take place in all fields of mathematics. Patterns are a part of teaching geometry. Reasoning, proving, problem solving, and representation processes are used in all content fields (NCTM, 2000, p. 31). Based on this, it can be stated that the mathematical content and teaching process should be followed in a consistent and balanced manner.

\section{References}

Aguilar, M. S., Rosas, A., Zavaleta, J. G. M., \& RomoVázquez, A. (2016). Exploring high-achieving students' images of mathematicians. International Journal of Science and Mathematics Education, 14(3), 527-548. https:// doi.org/10.1007/s10763-014-9586-1

Anning, A., \& Ring, K. (2004). Making sense of children's drawings. Maidenhead: Open University Press.
Bahr, D. L., \& de Garcia, L. A. (2010). Elementary mathematics is anything but elementary. Belmont, CA: Wadsworth.

Barbosa, A., \&Vale, I. (2016). Math trails: Meaningful mathematics outside the classroom with preservice teachers. Journal of the European Teacher Education Network, 11, 63-72.

Biatchford, P. (1996). Pupils' views on school work and school from 7 to 16 years. Research Papers in Education, 11(3), 263-288. https://doi. org/10.1080/0267152960110305

Borthwick, A. (2011). Children's perceptions of and attitudes towards their mathematics lessons. In C. Smith (Ed.), Proceedings of the British Society for Research into Learning Mathematics, 31(1), 37-42. London. Retrieved from https://bsrlm. org.uk/wp-content/uploads/2016/02/BSRLMIP-31-1-07.pdf

Bransford, J. D., Brown, A. L., \& Cocking, R. R. (Eds.). (2000). How people learn: Brain, mind, experience, and school. Washington DC: National Academy Press.

Bunting, C. J. (2006). Interdisciplinary teaching through outdoor education. Champaign, IL: Human Kinetics.

Burns, M., \& Silbey, R. (2000). So you have to teach math? Sound advice for K-6 teachers. Sausalito, CA: Math Solutions.

Carey, E., Devine, A., Hill, F., Dowker, A., McLellan, R., \& Szucs, D. (2019). Understanding mathematics anxiety: Investigating the experiences of UK primary and secondary school students. Retrieved from https://doi.org/10.17863/ CAM.37744

Clements, D. H., \& McMillen, S. (1996). Rethinking "concrete" manipulatives. Teaching Children Mathematics, 2(5), 270-279.

Cohen, L., Manion, L., \& Morrison, K. (2018). Research methods in education. New York: Routledge.

Cowan, P. (2006). Teaching mathematics: A handbook for primary and secondary school teachers. New York: Routledge.

Creswell, J. W. (2007). Qualitative inquiry and research design. Choosing among five approaches. Thousand Oaks, CA: Sage Publications, Inc. 
Creswell, J. W. (2016). 30 essential skills for the qualitative researcher. Thousand Oaks, California: SAGE Publications Ltd.

Davis, A., Goulding, M., \& Suggate, J. (2017). Mathematical knowledge for primary teachers. New York, NY: Routledge.

Department for Education and Employment (DfEE) (1999). The national curriculum: Handbook for primary teachers in England. London: DfEE and QCA.

Donovan, M. S., \& Bransford, J. D. (Eds.). (2005). How students learn: History, mathematics, and science in the classroom. Washington, DC: The National Academies Press.

Duncan, G. J., Dowsett, C. J., Claessens, A., Magnuson, K., Huston, A. C., Klebanov, P., ... Japel, C. (2007). School readiness and later achievement. Developmental Psychology, 43(6), 1428-1446. https://doi.org/10.1037/0012-1649.43.6.1428

Edwards, S. (2007). Primary mathematics for teaching assistants. USA: Routledge.

Ernst, K., \& Ryan, S. (2014). Success from the start: Your first years teaching elementary mathematics. Reston, VA: NCTM.

Eshun, B. A. (2004). Sex-differences in attitude of students towards mathematics in secondary schools. Mathematics Connection, 4(1), 1-13.

Fägerstam, E., \& Blom, J. (2013). Learning biology and mathematics outdoors: Effects and attitudes in a Swedish high school context. Journal of Adventure Education and Outdoor Learning, 13(1), 56-75. https://doi.org/10.1080/14729679.2011 .647432

Fraser, B. J., \& Kahle, J. B. (2007). Classroom, home and peer environment influences on student outcomes in science and mathematics: An analysis of systemic reform data. International journal of Science Education, 29(15), 1891-1909. https://doi.org/10.1080/09500690601167178

Freiman, V., Kadijevich, D., Kuntz, G., Pozdnyakov, S., \& Stedøy, I. (2009). Technological environments beyond the classroom. In E. J. Barbeau \& P. J. Taylors (Eds.), Challenging mathematics in and beyond the classroom (pp. 97-131). New York, NY: Springer.
Freitag, M. A. (2014). Mathematics for elementary school teachers: A process approach. Belmont, CA: Brooks/Cole.

Fuson, K. C. (1992). Research on learning and teaching addition and subtraction of whole numbers. In G. Leinhardt, R. T. Putnam, \& R. A. Hattrup (Eds.), Analysis of arithmetic for mathematics teaching (pp. 53-187). Hillsdale, New Jersey: Lawrence Erlbaum Associates, Inc.

Goulding, M. (1997). Learning to teach mathematics. London: David Fulton.

Gökçek, T., \& Güneş, G. (2011). How students perceive the math teacher? Mehmet Akif Ersoy University Journal of Social Sciences Institute, 3(4), 1-9.

Grevholm, B. (2010). Norwegian upper secondary school students' views of mathematics and images of mathematicians. In K. Kislenko (Ed.), Current state of research on mathematical beliefs XVI. Proceedings of the MAVI-16 Conference (pp. 120-136). Tallin, Estonia: Institute of Mathematics and Natural Sciences, Tallin University.

Hatısaru, V., \& Çetinkaya, B. (2012). illköğretim öğrencilerinin matematik ve matematikçi algılarının incelenmesi [Investigating elementary school students' perceptions of mathematics and mathematicians]. X. National Congress of Science and Mathematics Education, Niğde University, Niğde.

Haylock, D. (2010). Mathematics explained for primary teachers (4th edition). London: SAGE Publications.

Haylock, D., \& Thangata, F. (2007). Key concepts in teaching primary mathematics. London: SAGE Publications.

Hill, H. C., Blunk, M. L., Charalambous, C. Y., Lewis, J. M., Phelps, G. C., Sleep, L., \& Ball, D. L. (2008). Mathematical knowledge for teaching and the mathematical quality of instruction: An exploratory study. Cognition and Instruction, 26(4), 430-511. https://doi. org/10.1080/07370000802177235

Ho, W. K. (2008). Using history of mathematics in the teaching and learning of mathematics in Singapore. Paper presented at the 1st RICE, Singapore: Raffles Junior College. 
Holton, D., Cheung, K., Kesianye, S., de Losada, M. F., Leikin, R. Makrides, G., ... Yeap, B. (2009). Teacher development and mathematical challenge. In E. J. Barbeau \& P. J. Taylors (Eds.), Challenging mathematics in and beyond the classroom (pp. 133-170). New York, NY: Springer.

Julien, H. (2008). Content analysis. In L. M. Given (Ed.), The SAGE encyclopedia of qualitative research methods (pp. 120-122). Thousand Oaks, California: SAGE Publications, Inc.

Kennard, J. (2007). Outdoor mathematics. Mathematics Teaching Incorporating Micromath, 201, 16-18.

Kilpatrick, J., Swafford, J., \& Findell, B. (Eds.). (2001). Adding it up: Helping children learn mathematics. Washington, DC: National Academy Press.

Lee, J., \& Zeppelin, M. (2014). Using drawings to bridge the transition from student to future teacher of mathematics. International Electronic Journal of Elementary Education, 6(2), 333-346.

Lerman, S. (1998). Research on socio-cultural perspectives of mathematics teaching and learning. In J. Kilpatrick \& A. Sierpinska (Eds.), Mathematics education as a research domain: A search for identity. Vol. 1 (pp. 333-350). Dordrecht: Kluwer.

Ma, L. (1999). Knowing and teaching elementary mathematics: Teachers' understanding of fundamental mathematics in China and the United States. Mahwah, NJ: Lawrence Erlbaum Associates, Inc.

Malchiodi, C. A. (1998). Understanding children's drawings. New York: The Guilford Press.

Masingila, J. O., Davidenko, S., \& Prus-Wisniowska, E. (1996). Mathematics learning and practice in and out of school: A framework for connecting these experiences. Educational Studies in Mathematics, 31, 175-200. https://doi. org/10.1007/BF00143931

Merriam, S. B., \& Grenier, R. S. (2019). Qualitative research in practice: Examples for discussion and analysis. San Francisco, USA: Jossey-Bass.

Miles, M. B., \& Huberman, A. M. (1994). Qualitative data analysis: An expanded sourcebook. Thousand Oaks, CA: Sage Publications.
Ministry of National Education [MoNE]. (2018). Matematik dersi öğretim programı (Illkokul ve ortaokul 1, 2, 3, 4, 5, 6, 7 ve 8. siniflar) [Mathematics curriculum, grades 1 to 8]. Retrieved from http://mufredat.meb.gov.tr/ProgramDetay. aspx?PID=329

Mohamed, L., \& Waheed, H. (2011). Secondary students' attitude towards mathematics in a selected school of Maldives. International Journal of Humanities and Social Science, 1, 277-281.

National Council of Teachers of Mathematics. (2000). Principles and standards for school mathematics. Reston, VA: NCTM.

National Research Council. (2000). How people learn: Brain, mind, experience, and school. Expanded edition. Washington, DC: The National Academies Press. https://doi.org/10.17226/9853

Neale, D. C. (1969). The role of attitudes in learning mathematics. The Arithmetic Teacher, 16(8), 631-640.

Neuman, W. L. (2014). Social research methods: Qualitative and quantitative approaches. Harlow: Pearson.

Nicolaidou, M., \& Philippou, G. (2003). Attitudes towards mathematics, self-efficacy and achievement in problem solving. In M. A. Mariotti (Ed.), European research in mathematics education III (pp. 1-11). Pisa: University of Pisa.

Patton, M. Q. (2015). Qualitative research \& Evaluation methods: Integrating theory and practice. USA: Sage Publications, Inc.

Picker, S. H., \& Berry, J. S. (2000). Investigating pupils' images of mathematicians. Educational Studies in Mathematics, 43, 65-94. https://doi. org/10.1023/A:1017523230758

Punch, S. (2002). Research with children: The same or different from research with adults? Childhood, 9(3), 321-341. https://doi.org/10.1177/09075682020 09003005

Reys, R. E., \& Nohda, N. (Eds.). (1994). Computational alternatives for the twenty-first century: Crosscultural perspectives from Japan and the United States. Reston, VA: NCTM.

Richardson, K. M. (2004). Designing math trails for the elementary school. Teaching Children Mathematics, 11(1), 8-14. 
Rock, D., \& Shaw, J. M. (2000). Exploring children's thinking about mathematicians and their work. Teaching Children Mathematics, 6(9), 550-555.

Sanchez, K., Zimmerman, L., \& Ye, R. (2004). Secondary students' attitudes toward mathematics. Academic Exchange Quarterly, 8(2), 56-60.

Thanheiser, E., Whitacre, I., \& Roy, G. (2014). Mathematical content knowledge for teaching elementary mathematics: A focus on wholenumber concepts and operations. The Mathematics Enthusiast, 11(2), 217-266.

Toluk Uçar, Z., Pişkin, M., Akkaş, E. N., \& Taş̧̧ı, D. (2010). İlköğretim öğrencilerinin matematik, matematik öğretmenleri ve matematikçiler hakkındaki inançları [Elementary students' beliefs about mathematics, mathematics' teachers and mathematicians]. Eğitim ve Bilim, 35(155), 131-144.

Weber, S., \& Mitchell, C. (1999). Drawing ourselves into teaching: Studying the images that shape and distort teacher education. Teaching and Teacher Education, 12(3), 303-313. https://doi. org/10.1016/0742-051X(95)00040-Q

Yavuz Mumcu, H. (2020). Ortaokul öğrencilerinin matematik algılarının resmetme yoluyla incelenmesi [Investigation of secondary school students' math perceptions through drawings]. Kastamonu Eğitim Dergisi, 28(1), 371-388. https:// doi.org/10.24106/kefdergi.3620 